\title{
The Impact of Cognitive Scaffolding on Iranian EFL Learners' Speaking Skill
}

\author{
Maryam Razaghi \\ Department of English, Shiraz Branch, Islamic Azad University, Shiraz, Iran, \\ maryam_razaghi82@yahoo.com
}

\section{Mohammad Sadegh Bagheri}

Corresponding author, Department of English, Shiraz Branch, Islamic Azad University, Shiraz,Iran,bagheries@gmail.com

\section{Mortaza Yamini}

Zand Institute of Higher Education, Shiraz, Iran, mortazayamini@gmail.com

Taking into account the three key features of scaffolding, namely, contingency, fading and the transfer of responsibility, the present study investigated the role of cognitive scaffolding in speaking and its components (i.e. grammar, vocabulary, pronunciation, discourse management, interactive communication). Moreover, the possible moderating effect of learners' proficiency level was examined. Four groups of 30 female Iranian learners of English in a language school participated in this study, two of which were chosen from upper-intermediate learners, while the other two groups included learners studying at pre-intermediate levels. The results of the two-way ANCOVA tests indicated that cognitive scaffolding could foster speaking skill and its components. Besides, it was found that learners' level of proficiency did not mediate the impact of scaffolding on the studied dependent variables. Therefore, both upper-intermediate and pre-intermediate learners equally benefited from cognitive scaffolds. The study offers a number of pedagogical implications which are discussed.

Keywords: cognitive scaffolding, speaking, grammar, vocabulary, pronunciation, discourse management, interactive communication

\section{INTRODUCTION}

Speaking as a language skill is an act of communication which plays an important role in learners' language development. The spoken form has generally been regarded as the primary form of a language upon which the written form is essentially dependent (Hughes, 2002). However, the productive skill of speaking in a second or foreign language has received attention only in relatively recent years (McCarthy \& O'Keeffe,

Citation: Razaghi, M., Bagheri, M. S., \& Yamini, M. (2019). The Impact of Cognitive Scaffolding on Iranian EFL Learners' Speaking Skill. International Journal of Instruction, 12(4), 95-112. https://doi.org/10.29333/iji.2019.1247a 
2006). Even nowadays, as Hughes (2002) mentions very little attention is paid to speaking in its own right to be judged by its own distinctive criteria in the world of linguistics, or of language teaching. Moreover, developing the ability to successfully get messages across and interact in the target language constitutes one of the greatest challenges to learners and teachers (Waniek-Klimczak \& Pawlak, 2015).

Having such a demanding job at hand, language teachers always look for ways to improve students' competence and performance, seeking help from various teaching methods and theories. One of the influential theories of learning, Socio-Cultural Theory of Mind developed by Vygotsky (1978), has greatly affected language teaching. Vygotsky (1978) argued that learning is a social process which occurs in the interaction between individuals and such interaction within the Zone of Proximal Development (ZPD) acts as mediation for language acquisition. He considered ZPD, "the distance between the actual development level as determined by independent problem solving and the level of potential development as determined through problem-solving under adult guidance or in collaboration with more capable peers," (Vygotsky, 1978, p. 86) as a key element in the learning process.

When moving from the level of actual development to the potential developmental level in ZPD, scaffolding is required to represent assistance from the guidance or collaboration (Bruner, 1975). According to Maybin, Mercer, \& Stierer, (1992), scaffolding is the temporary supportive interaction through which novices are assisted by experts or other peers to develop new skills, concepts or higher levels of understanding.

This study benefits from Van de Pol et al.'s (2010) conceptual model of scaffolding. According to this model, scaffolding has three main features: contingency, fading, and transfer of responsibility. Contingency refers to adapting support to the student's needs (e.g., Wood, Wood, \& Middleton, 1978). In order to do this, one must diagnose the student's current understanding prior to providing the support (e.g., Wittwer \& Renkl, 2008). Via fading, i.e., decreasing support and gradual withdrawal of scaffolding, responsibility for learning or further task performance can be gradually transferred so that learners take control of their own learning.

Van de Pol, Volman, and Beishuizen, (2010) proposed an integrative framework for the analysis of scaffolding strategies that includes five scaffolding intentions (what is scaffolded) and six scaffolding means (how is scaffolding taking place). Means can be of metacognitive, cognitive or affect in nature. Direction maintenance, a metacognitive intention, refers to maintaining the learner's pursuit of a particular objective. The two cognitive intentions are cognitive structuring (providing explanatory and belief structures that organize and justify) and reduction of the degrees of freedom (taking over those parts of a task that the student is not yet able to perform and thereby simplification of the task for the student). Two affective intentions are contingency management/frustration control and recruitment. Contingency management/frustration control is defined as the facilitation of student performance via a system of rewards and punishment while keeping students motivated through reducing frustration. Recruitment 
concerns getting students interested in a task and helping them adhere to its requirements.

Six scaffolding means according to Van de Pol et al. (2010) include 1) Feeding back: the provision of information regarding the student's performance to the student himself. 2) Hints: the provision of clues or suggestions by the teacher to help the student go forward. 3) Instructing: the teacher telling the students what to do or explanation of how something must be done and why. 4) Explaining: the provision of more detailed information or clarification by the teacher. 5) Modeling: the process of offering behavior for imitation. 6) Questioning: asking students questions that require an active linguistic and cognitive answer.

Throughout the years, researchers have mainly chosen a descriptive approach towards scaffolding which has provided us with useful knowledge on the appearances of scaffolding. However, as Van de Pol et al. (2010) mention much remains unknown about its effectiveness. In addition, the effectiveness studies have mainly been conducted in parent-child and one-to-one tutoring contexts (e.g. (Mattanah, Pratt, Cowan, \& Cowan, 2005; Pino-Pasternak, Whitebread, \& Tolmie, 2010; Pratt \& SavoyLevine, 1998; Stright, Neitzel, Sears, \& HokeSinex, 2001; Wood \& Middleton, 1975). Consequently, due to few (quasi-) experimental studies conducted in classroom situations, more research should be done on the effects of scaffolding in such contexts.

Moreover, in spite of a number of studies on the role of scaffolding in some language skills (e.g., Huggings \& Edwards, 2011; Rahimi \& Tahmasebi, 2010), very few have focused on examining the effectiveness of scaffolding in developing EFL learners' speaking ability, and there is no empirical backing available hinting to the effective role of cognitive scaffolds in promoting the speaking skill and its various components. In addition, no research in the literature investigated the moderating role of proficiency on the effectiveness of cognitive scaffolding. Nor has any study implemented Van de Pol et al.'s conceptual model and framework for the analysis of scaffolding. To fill the research gap, the study at hand sets out to measure the effectiveness of cognitive scaffolding in promoting different components of EFL learners' speaking skill. More specifically, this study is aimed at answering the following questions:

1.Does cognitive scaffolding significantly improve Iranian EFL learners' speaking skill?

2.Does cognitive scaffolding significantly improve Iranian EFL learners' grammar?

3.Does cognitive scaffolding significantly improve Iranian EFL learners' vocabulary?

4.Does cognitive scaffolding significantly improve Iranian EFL learners' pronunciation?

5.Does cognitive scaffolding significantly improve Iranian EFL learners' discourse management?

6.Does cognitive scaffolding significantly improve Iranian EFL learners' interactive communication?

7.Does the level of proficiency act as a moderator variable in the impact of cognitive scaffolding?

\section{LITERATURE REVIEW}

Scaffolding is linked to Vygotsky's (1978) sociocultural theory and specifically to his Zone of Proximal Development. ZPD is the difference between what learners can do on 
their own and what they can do when given support. According to Maybin, Mercer \& Stierer (1992), scaffolding refers to the temporary but essential nature of supportive interaction through which novices are assisted by experts or other peers to develop new skills, concepts or higher levels of understanding.

Previous studies on scaffolding have shown that it positively affects the performance of students (e.g., Helmer-Salasoo, 2001; Mertzman, 2008; Murphy \& Messer, 2000; Rueda, Monz \& Higareda, 2004). In the context of language learning, a number of researchers have probed into the effects of scaffolding strategies in reading comprehension development (e.g., Attarzadeh, 2011; Ghafar Samar \& Dehghan, 2013; Magno, 2010; Poorahmadi, 2009; Rahimi \& Ghanbari, 2011; Rahimi \& Tahmasebi, 2010), reporting positive effects for scaffolding strategies. The effect of scaffolding strategies on writing has also been the focus of some studies (e.g. Aljaafreh \& Lantolf, 1994; Baleghizadeh,Timcheh Memar, \& Timcheh Memar, 2011; De Guerrero \& Villamil, 2000; Hemmati \& Mortazavi, 2017; Jafarigohar \& Mortazavi, 2016; Mortazavi, Jafarigohar, Rouhi \& Soleimani, 2016; Riazi \& Rezai, 2011), all concluding that scaffolding techniques foster the writing skill and aspects pertinent to it (e.g. writing self-regulation).

Literature also includes studies endorsing the positive impacts of scaffolds on grammar (Donato, 1994; Danli, 2008), and vocabulary (Shoari \& Assadi Aidinlou, 2015). There are, however, only a few studies examining the effect of scaffolds on speaking. Most research on scaffolding speaking were descriptive in nature, aiming to list the scaffolding strategies employed by teachers (e.g., Mulyana, 2012; Tyas, 2009). Among few studies examining the role of scaffolds on speaking, is that of Arfaei Zarandi and Rahbar (2014). In their study, the experimental group received interactive strategies of scaffolding and the control group experienced routine speaking instruction in ten sessions. The results of paired-samples t-test showed that interactive scaffolding strategies were effective in enhancing EFL learners' speaking ability.

In another study, Khaliliaqdam (2014) examined the role of scaffolding via communicative activities in terms of the development of basic speech on foreign language adult learners. The results showed that language input from the teacher provided cognitive structure and an organizational model of language for the students and the learners' speech level improved at the end of the term.

Abbasian, Fatehi, Ghahfarokhi \& Ghasemi (2015) investigated the effect of off-task scaffolded feedback on young English learners speaking skill. In the experimental group, learners were scaffolded by receiving off-task recorded feedback from the teacher; in the control group, learners had the same tasks but received on the spot feedback. Results revealed that the learners' speaking ability in the experimental group was significantly higher than the control group. The researchers related this difference to the type of scaffolding and the feedback the learners had received and the reflection time they had.

As the literature reveals, scaffolding has been subject to a lot of research (e.g., Attarzadeh, 2011; Ghafar Samar \& Dehghan, 2013; Mertzman, 2008). However, most studies have been descriptive in nature (e.g., Mulyana, 2012; Tyas, 2009) and there 
seems to be a need to focus more on the effectiveness of scaffolding. Moreover, among the studies targeting to scrutinize the effectiveness of scaffolding, speaking as a language skill is one of those areas which needs more attention. Furthermore, the interpretation of the concept of scaffolding in current research has been highly diverse (Jacobs, 2001). Taking into account the three most common characteristics of scaffolding, the present study was aimed at filling the research gap by investigating the role of cognitive scaffolding in speaking and its components. Moreover, the possible moderating effect of learners' proficiency level on the effectiveness of scaffolding was examined.

\section{METHOD}

\section{Participants}

Four groups of 30 female Iranian learners of English in a language institute participated in this study. The participants were selected from intact pre-intermediate and upperintermediate classes. All participating learners had enrolled in a speaking English course based on a syllabus encouraging the development of oral skills. Two groups of learners were upper-intermediate and the other two were pre-intermediate learners. The age of the participants ranged between 17 and $38(\square=22.48, S D=7.32)$.

Due to the fact that the number of learners in each class did not exceed 20, learners in these groups were chosen from 8 different classes: four upper-intermediate and four preintermediate classes. Each of the conditions was organized in a way as to include learners of no more than two classes. In other words, the 8 classes comprised 4 conditions or groups. The same teacher, the researcher, taught the learners in all conditions. From the members of each class, 15 were randomly selected as participants prior to the treatment. Although all the learners in these classes received the treatment and took the pretests and the posttests, only the scores of the selected participants were taken into account for data analysis. From these four groups, two were chosen from four intact classes of pre-intermediate learners and two were selected from four intact classes of upper-intermediate learners. One of the upper-intermediate groups was assigned to be the experimental group (EX-UI) and the other was chosen to be the control group (CGUI). Similarly, one of the pre-intermediate groups was selected as the pre-intermediate experimental group (EX-PI), and the other the pre-intermediate control group (CG-PI). The experimental groups across the two proficiency levels received cognitive scaffolding as to be discussed in the procedures section. The control groups, however, did not benefit from scaffolding techniques.

Table 1 illustrates the grouping of the participants for the present study.

Table 1

The Participants and the Treatment They Received

\begin{tabular}{llll}
\hline Groups & Number of learners & Treatment & Proficiency Level \\
\hline EX-UI & 30 & Cognitive scaffold & Upper-intermediate \\
EX-PI & 30 & Cognitive scaffold & Pre-intermediate \\
CG-UI & 30 & No scaffolds & Upper-intermediate \\
CG-PI & 30 & No scaffolds & Pre-intermediate \\
\hline
\end{tabular}




\section{The English Course}

Consisting of 18 sessions, the course was designed to increase learners' speaking skill and required them to talk about given topics and take part in class discussions.

\section{Instrumentation}

\section{Oxford Placement test}

Oxford Placement Test (OPT) was used to ensure the homogeneity of the participants prior to the treatment. It consisted of two parts: listening (10 minutes) and grammar (1 hour).

\section{Cambridge English: Preliminary (PET) speaking test}

In the Cambridge English: Preliminary Speaking test, candidates are examined in pairs by two examiners. One of the examiners acts as an interlocutor who directs the test and awards a mark for global achievement and the other as an assessor who uses the analytical assessment scales to award marks for grammar, vocabulary, discourse management, pronunciation, and interactive communication. The test takes between 10 to 12 minutes and consists of four parts which are designed to elicit a wide range of speaking skills from the candidates.

\section{Cambridge English: First (FCE) oral exam}

The paired format for the Cambridge English: First Speaking test (two examiners and two candidates) takes 14 minutes. One of the examiners conducts the test and gives a global assessment of each candidate's performance based on the global achievement scale. The other, does not take part in the interaction and awards marks by applying performance descriptors from the analytical assessment scales for grammar, vocabulary, pronunciation, discourse management and interactive communication. The Speaking test consists of four parts, each part focuses on a different type of interaction: between the interlocutor and each candidate, between the two candidates, and among all three. The patterns of discourse vary within each part of the test.

\section{Procedures}

On the first day of the term, the participating learners in all eight classes were given the Oxford Placement Test (OPT) to ensure the homogeneity of participants within each proficiency level. The performances of the EX-PI and CG-PI in the OPT test were compared using an independent t-test. The result of the t-test run on the OPT data for the pre-intermediate participants demonstrated no statistically significant differences between the EX-PI and CG-PI, $\mathrm{t}_{(1,58)}=.03, \mathrm{p}>0.05$.

Further, another independent $t$-test was run to compare the performance of the EX-UI and CG-UI, the result of which indicated that the two groups were homogenous in terms of proficiency and no statistically significant differences were detected between their OPT scores, $\mathrm{t}_{(1,58)}=1.11, \mathrm{p}>0.05$.

Having made certain that the participants in the control and experimental groups within each proficiency level were homogenous, the researcher administered the pretests. The pretests included the administration of the oral section of Preliminary English Test 
(PET) to the pre-intermediate learners and the oral section of the First Certificate in English (FCE) test to the upper-intermediate learners.

The next session, the treatment, which lasted for 18 sessions, began. During the treatment, learners were provided with the opportunity to take part in both individual and pair/group speaking activities. The learners were asked to justify a choice or describe a photo individually or discuss ideas in pairs/groups. The treatment included the provision of cognitive scaffolding during speaking activities based on the model by Van de Pol et al. (2010) as explained below.

Scaffolds were designed to possess the three features identified by Van de Pol et al. (2010), namely contingency, fading, and transfer of responsibility. As scaffolds are needed to have contingency (i.e. to be adjusted support), the teacher's support was adapted to the current level of the students' performance. The teacher used one-on-one interactions with learners to dynamically assess and determine their competence level. In other words, throughout the treatment, the teacher asked learners questions to elicit their oral responses. The questions were designed to elicit arguments and justifications so that the learners would be encouraged to speak long enough for the teacher to be able to estimate their competence with regard to the knowledge of vocabulary and structure and to realize where their pronunciation problems lie. Besides, to gain insight into the current level of participants in terms of interactive communication and discourse management skills, at the outset of each session, the teacher also arranged some pair activities in which learners were asked to discuss a given topic and reach an agreement. The teacher monitored learners while they were engaged in pair work and took notes about the communicational skills. This assessment gave the teacher insight into the proper time to offer scaffolds.

The second common characteristic is fading or the gradual withdrawal of scaffolding. To incorporate this characteristic into the assistance offered in this study, the scaffolds were provided in three phases during which they were gradually dismantled. In other words, the amount of scaffold decreased throughout three phases. The transfer of responsibility, closely related to fading, was also achieved as scaffolds were withdrawn gradually, as the learners had to shoulder more responsibility as the amount of scaffolds they received declined. In the study at hand, the intentions that support students' cognitive activities were focused on. In other words, scaffolds were aimed at cognitive structuring and reduction of freedom. Table 2 depicts how cognitive scaffolds were offered in the first phase to develop various components of the speaking skill.

Table 2

Cognitive Scaffolds Offered in the First Phase

\begin{tabular}{llllll}
\hline $\begin{array}{l}\text { Speaking } \\
\text { component }\end{array}$ & Grammar & Vocabulary & Pronunciation & $\begin{array}{l}\text { Interactive } \\
\text { Communication }\end{array}$ & $\begin{array}{l}\text { Discourse } \\
\text { Management }\end{array}$ \\
\hline Feedback & $\begin{array}{l}\text { The teacher provided } \\
\text { the learners with } \\
\text { feedback on the } \\
\text { correctness of the } \\
\text { grammatical structures } \\
\text { they had used in the } \\
\text { activity. }\end{array}$ & $\begin{array}{l}\text { The teacher } \\
\text { provided the } \\
\text { learners with } \\
\text { feedback on the } \\
\text { correctness of the } \\
\text { vocabulary they } \\
\text { had used in the }\end{array}$ & $\begin{array}{l}\text { The teacher } \\
\text { provided the } \\
\text { learners with } \\
\text { feedback on the } \\
\text { correctness of their } \\
\text { pronunciation. }\end{array}$ & $\begin{array}{l}\text { The teacher provided } \\
\text { the learners with } \\
\text { feedback on the } \\
\text { efficacy of the } \\
\text { techniques and the } \\
\text { correctness and the } \\
\text { properness of the }\end{array}$ & $\begin{array}{l}\text { The teacher } \\
\text { provided the } \\
\text { learners with } \\
\text { feedback on the } \\
\text { correctness of the } \\
\text { phrases they had } \\
\text { used to connect }\end{array}$ \\
\hline
\end{tabular}




\begin{tabular}{|c|c|c|c|c|c|}
\hline & & activity. & & phrases and sentences & ideas and sentences \\
\hline Hint & $\begin{array}{l}\text { The teacher made use } \\
\text { of body language to } \\
\text { hint the use of certain } \\
\text { structures. }\end{array}$ & $\begin{array}{l}\text { The teacher } \\
\text { provided clues or } \\
\text { suggestions to help } \\
\text { the student select } \\
\text { the appropriate } \\
\text { words/expressions } \\
\text { they needed to get } \\
\text { their message } \\
\text { across. }\end{array}$ & $\begin{array}{l}\text { The teacher stopped } \\
\text { the learners in case } \\
\text { of wrong } \\
\text { pronunciation/inton } \\
\text { ation and provided } \\
\text { clues to trigger the } \\
\text { production of the } \\
\text { correct } \\
\text { pronunciation. }\end{array}$ & $\begin{array}{l}\text { The teacher made use } \\
\text { of body language to } \\
\text { hint the use of certain } \\
\text { structures. }\end{array}$ & $\begin{array}{l}\text { The teacher hinted } \\
\text { the necessity of } \\
\text { speaking rationally } \\
\text { and coherently. }\end{array}$ \\
\hline Instructing & $\begin{array}{l}\text { The teacher provided } \\
\text { detailed instruction of } \\
\text { the tasks. }\end{array}$ & $\begin{array}{l}\text { The teacher } \\
\text { provided detailed } \\
\text { instruction of the } \\
\text { tasks. }\end{array}$ & $\begin{array}{l}\text { The teacher } \\
\text { provided detailed } \\
\text { instruction of the } \\
\text { tasks. }\end{array}$ & $\begin{array}{l}\text { The teacher provided } \\
\text { detailed instruction of } \\
\text { the tasks. }\end{array}$ & $\begin{array}{l}\text { The teacher } \\
\text { provided detailed } \\
\text { instruction of the } \\
\text { tasks. }\end{array}$ \\
\hline Explaining & $\begin{array}{l}\text { The teacher provided } \\
\text { explanations pertaining } \\
\text { to the required } \\
\text { structures to } \\
\text { accomplish the } \\
\text { speaking task. }\end{array}$ & $\begin{array}{l}\text { The teacher } \\
\text { provided } \\
\text { explanations with } \\
\text { regard to the } \\
\text { meaning and usage } \\
\text { of the } \\
\text { words/expressions. }\end{array}$ & $\begin{array}{l}\text { The teacher } \\
\text { provided } \\
\text { explanations about } \\
\text { the phonological } \\
\text { rules and the proper } \\
\text { ways of } \\
\text { pronouncing words. }\end{array}$ & $\begin{array}{l}\text { The teacher provided } \\
\text { explanations } \\
\text { pertaining to the } \\
\text { phrases used for } \\
\text { asking for ideas, } \\
\text { agreeing, and } \\
\text { disagreeing. }\end{array}$ & $\begin{array}{l}\text { The teacher } \\
\text { provided } \\
\text { explanations } \\
\text { pertaining to the } \\
\text { required structures } \\
\text { to accomplish the } \\
\text { speaking task. }\end{array}$ \\
\hline Modeling & $\begin{array}{l}\text { The teacher modeled } \\
\text { the use of grammatical } \\
\text { structures. (e.g. for } \\
\text { photo description } \\
\text { activities, the teacher } \\
\text { modeled the use of } \\
\text { present continuous } \\
\text { tense) }\end{array}$ & $\begin{array}{l}\text { The teacher } \\
\text { modeled the use of } \\
\text { words/explanations. }\end{array}$ & $\begin{array}{l}\text { The teacher } \\
\text { modeled } \\
\text { pronouncing new } \\
\text { words. }\end{array}$ & $\begin{array}{l}\text { The teacher modeled } \\
\text { asking for opinions, } \\
\text { agreeing/disagreeing. }\end{array}$ & $\begin{array}{l}\text { The teacher } \\
\text { modeled the use of } \\
\text { cohesive devices, } \\
\text { related vocabulary, } \\
\text { grammatical } \\
\text { devices and } \\
\text { discourse markers. }\end{array}$ \\
\hline Questioning & $\begin{array}{l}\text { The teacher asked } \\
\text { thought-provoking } \\
\text { questions eliciting } \\
\text { decisions about the use } \\
\text { of certain grammatical } \\
\text { structures in speaking } \\
\text { activities (e.g. what } \\
\text { structure do you need } \\
\text { to make deductions } \\
\text { about the photo?) }\end{array}$ & $\begin{array}{l}\text { The teacher asked } \\
\text { thought-provoking } \\
\text { questions eliciting } \\
\text { decisions about the } \\
\text { use of certain } \\
\text { words in speaking } \\
\text { activities. }\end{array}$ & $\begin{array}{l}\text { The teacher asked } \\
\text { questions about } \\
\text { how phonological } \\
\text { rules could be } \\
\text { extracted from } \\
\text { some examples. }\end{array}$ & $\begin{array}{l}\text { The teacher asked } \\
\text { questions about the } \\
\text { ways learners could } \\
\text { ask for ideas, and } \\
\text { demonstrate } \\
\text { agreement/disagreem } \\
\text { ent. }\end{array}$ & $\begin{array}{l}\text { The teacher asked } \\
\text { questions eliciting } \\
\text { decisions about the } \\
\text { use of cohesive } \\
\text { devices, related } \\
\text { vocabulary, } \\
\text { grammatical } \\
\text { devices and } \\
\text { discourse markers. }\end{array}$ \\
\hline
\end{tabular}

The first phase of scaffolding lasted for 10 sessions during which the teacher modeled the activities, provided explanations and feedback, made use of thought-provoking hints, questioning, and instructing. In the second phase of offering the scaffolds which lasted for 5 sessions, the teacher only made use of explanations and feedback. Finally, in the final 3 sessions of the treatment, which comprised the third and last phase of scaffold provision, the teacher merely offered explanations.

While the learners in the experimental conditions received scaffolds during the aforementioned phases, the control group learners were merely asked to justify a choice or express agreement/disagreement, describe photos, or discuss ideas and reach agreements in pairs/groups. They were not provided with hints or feedbacks. Nor were the activities modeled for them. They did not benefit from the questions, instruction or explanations either. In order to provide fair circumstances for learners in the control group, the detailed feedback on their performance was offered to them after the posttest.

Nine weeks after the pretest, the participants were given the PET and FCE posttests. The posttests included the administration of the oral section of PET to the pre-intermediate learners and the oral section of the FCE test to the upper-intermediate learners. 
In order to ensure the reliability of scores, inter-rater reliability was established through checking the consistency between the two raters. To check inter rater reliability a Pearson-product moment correlation coefficient was performed and the results were as follows: Pretest Speaking components .89, Posttest Speaking components .98, pretest global achievement .87 , posttest global achievement .89 , pretest vocabulary .93 , posttest vocabulary .86 , pretest grammar .87 , posttest grammar .97 , pretest pronunciation .89 , posttest pronunciation .89 , pretest discourse management .92 , posttest discourse management 88 , pretest interactive communication .84 , posttest interactive communication .86. Hence, it was established that the two raters' ratings enjoyed considerable degrees of inter-rater reliability.

\section{FINDINGS}

Having made sure, the prerequisite condition of normality was met, the researcher ran a series of ANCOVA tests to probe the effect of cognitive scaffolds and the moderating role of proficiency on various components of the speaking skill as measured by the speaking section of PET and FCE tests.

\section{The Effect of Cognitive Scaffolding on Speaking}

To answer the first research question and to probe into the impact of cognitive scaffolding on participants' speaking skill and the moderating role of learners' proficiency, a two-way ANCOVA was run to investigate the effect of cognitive scaffolding and the level of proficiency on the participants' speaking ability. Table 3 displays the results of the between-subject effects for the speaking test.

Table 3

Two-Way ANCOVA: Tests of Between-Subjects Effects, Speaking Test by Groups* Proficiency

\begin{tabular}{|c|c|c|c|c|c|c|c|}
\hline Source & $\begin{array}{l}\text { Type III Sum } \\
\text { Squares }\end{array}$ & $\begin{array}{l}\text { of } \\
\text { Df }\end{array}$ & Mean Square & $\mathrm{F}$ & Sig. & $\begin{array}{l}\text { Partial } \\
\text { Squared }\end{array}$ & Eta \\
\hline Pretest & 299.88 & 1 & 299.88 & 143.74 & .00 & .55 & \\
\hline Groups & 2523.40 & 1 & 2523.40 & 1209.55 & .00 & .91 & \\
\hline Proficiency & .75 & 1 & .75 & .36 & .54 & .00 & \\
\hline Groups * Proficiency & .05 & 1 & .05 & .02 & .87 & .00 & \\
\hline Total & 40944.00 & 240 & & & & & \\
\hline
\end{tabular}

As it can be seen in Table 3, significant differences were detected between the performances of the learners in the scaffolding condition $(M=21.21, S D=2.26)$, and the control group $(M=11.85, S D=2.01)$, in the speaking test when the pretest scores were taken as the covariate to account for the possible variances prior to the treatment, $F$ $(1,116)=1209.55, p<.05 ; \eta 2=.91$. Besides, no significant interaction was detected between the groups and proficiency levels, $F(1,116)=.02, p>.05 ; \eta 2=.00$, which indicated no mediating effect for learners' proficiency level, pointing out to the efficacy of the scaffolding techniques across the two proficiency levels. In other words, both proficiency levels could equally benefit from cognitive scaffolding.

\section{The Effect of Cognitive Scaffolding on Grammar}

To find the answer to the second research question which concerned the impact of cognitive scaffolding on participants' grammar and the moderating role of learners' 
proficiency, the researcher ran a two-way ANCOVA. Table 4 shows the results of the between-subject effects for the grammar test.

Table 4

Two-Way ANCOVA: Tests of Between-Subjects Effects, Grammar Test by Groups* Proficiency

\begin{tabular}{lllllll}
\hline Source & Type III Sum of Squares & Df & Mean Square & F & Sig. & Partial Eta Squared \\
\hline Pretest & 5.31 & 1 & 5.31 & 18.16 & .00 & .13 \\
Groups & 116.41 & 1 & 116.41 & 397.49 & .00 & .77 \\
Proficiency & .07 & 1 & .07 & .25 & .61 & .00 \\
Groups * Proficiency & .00 & 1 & .00 & .00 & .97 & .00 \\
\hline Total & 1296.00 & 120 & & & & \\
\hline
\end{tabular}

As it can be seen in Table 4, significant differences were detected between the performances of the learners in the scaffolding condition $(M=4.06, S D=.57)$, and the control group $(M=2.10, S D=.57)$, in the grammar component when the pretest scores were taken as the covariate to account for the possible variances prior to the treatment, $F(1,116)=397.49, p<.05 ; \eta 2=.77$. Further, as Table 4 shows, the results of the grammar two-way ANCOVA test revealed no significant interaction between the groups and proficiency levels, $F(1,116)=.00, p>.05 ; \eta 2=.00$, indicating no moderating effect for learners' proficiency level, pointing out to the efficacy of the scaffolding techniques regarding the improvement of grammar across the two proficiency levels.

\section{The Effect of Cognitive Scaffolding on Vocabulary}

To scrutinize the impact of cognitive scaffolding on vocabulary which was the main concern of the third research question and to find out about the moderating role of learners' proficiency, the researcher ran a two-way ANCOVA. Table 5 shows the results of the between-subject effects for the vocabulary test.

Table 5

Two-Way ANCOVA: Tests of Between-Subjects Effects, Vocabulary Test by Groups* Proficiency

\begin{tabular}{lllllll}
\hline Source & Type III Sum of Squares & Df & Mean Square & F & Sig. & Partial Eta Squared \\
\hline Pretest & 17.85 & 1 & 17.85 & 81.65 & .00 & .41 \\
Groups & 130.74 & 1 & 130.74 & 597.92 & .00 & .83 \\
Proficiency & .06 & 1 & .06 & .30 & .58 & .00 \\
Groups * Proficiency & .69 & 1 & .69 & 3.16 & .07 & .02 \\
\hline Total & 1296.00 & 120 & & & & \\
\hline
\end{tabular}

As shown in Table 5, significant differences were detected between the performances of the learners in the scaffolding condition $(M=4.03, S D=.63)$ and the control group $(M$ $=2.06, S D=.57)$, in the vocabulary component when the pretest scores were taken as the covariate to account for the possible variances prior to the treatment, $F(1,116)=$ $597.92, p<.05 ; \eta 2=.83$. Further, as Table 5 shows, the results of the vocabulary twoway ANCOVA test revealed no significant interaction between the groups and proficiency levels, $F(1,116)=.3 .16, p>.05 ; \eta 2=.02$, showing no moderating effect for learners' proficiency level, pointing out to the efficacy of the scaffolding techniques regarding the improvement of vocabulary knowledge across the two proficiency levels. In other words, cognitive scaffolding could be fruitful for both proficiency levels in terms of promoting vocabulary knowledge. 


\section{The Effect of Cognitive Scaffolding on Pronunciation}

In order to answer the fourth research question which pertained to the impact of cognitive scaffolding on participants' pronunciation skills and to explore the possible moderating role of learners' proficiency in mediating the impact of scaffolds on pronunciation, a two-way ANCOVA was run. Table 6 shows the results of the betweensubject effects for the pronunciation component.

Table 6

Two-Way ANCOVA: Tests of Between-Subjects Effects, Pronunciation Test by Groups* Proficiency

\begin{tabular}{lllllll}
\hline Source & Type III Sum of Squares & Df & Mean Square & F & Sig. & Partial Eta Squared \\
\hline Pretest & 8.60 & 1 & 8.60 & 30.06 & .00 & .20 \\
Groups & 110.81 & 1 & 110.81 & 387.34 & .00 & .77 \\
Proficiency & 1.31 & 1 & 1.31 & 4.57 & .03 & .03 \\
Groups * Proficiency & .01 & 1 & .01 & .06 & .79 & .00 \\
\hline Total & 1341.00 & 120 & & & & \\
\hline
\end{tabular}

As Table 6 illustrates, statistically significant differences were detected between the performances of the learners in the scaffolding condition $(M=4.10, S D=.62)$, and the control group $(M=2.06, S D=.66)$, in the pronunciation component when the pretest scores were taken as the covariate to account for the possible variances prior to the treatment, $F(1,116)=387.34, p<.05 ; \eta 2=.77$. Moreover, the results of the two-way ANCOVA test revealed no significant interaction between the groups and proficiency levels, $F(1,116)=.06, p>.05 ; \eta 2=.00$, indicating no moderating effect for learners' proficiency level. This means that the scaffolding technique was helpful with regard to the improvement of pronunciation in both proficiency levels.

\section{The Effect of Cognitive Scaffolding on Discourse Management}

In order to examine the impact of cognitive scaffolding on participants' discourse management skills and to probe into the possible moderating role of learners' proficiency in mediating the impact of scaffolds on discourse management skills, the researcher ran a two-way ANCOVA. Table 7 shows the results of the between-subject effects for the discourse management component.

Table 7

Two-Way ANCOVA: Tests of Between-Subjects Effects, Discourse management Test by Groups* Proficiency

\begin{tabular}{lllllll}
\hline Source & Type III Sum of Squares & Df & Mean Square & F & Sig. & Partial Eta Squared \\
\hline Pretest & 6.33 & 1 & 6.33 & 17.12 & .00 & .13 \\
Groups & 129.83 & 1 & 129.83 & 351.05 & .00 & .75 \\
Proficiency & .57 & 1 & .57 & 1.55 & .21 & .01 \\
Groups * Proficiency & 1.00 & 1 & 1.00 & 2.70 & .10 & .02 \\
\hline Total & 1314.00 & 120 & & & & \\
\hline
\end{tabular}

As Table 7 depicts, significant differences were detected between the performances of the learners in the scaffolding condition $(M=4.10, S D=.62)$, and the control group $(M$ $=2.06, S D=.66)$, in the discourse management component when the pretest scores were taken as the covariate to account for the possible variances prior to the treatment, $F(1$, $116)=129.83, p<.05 ; \eta 2=.75$. Moreover, as Table 7 displays, the results of the discourse management two-way ANCOVA test revealed no significant interaction 
between the groups and proficiency levels, $F(1,116)=2.70, p>.05 ; \eta 2=.02$, indicating no moderating effect for learners' proficiency level, pointing out to the efficacy of the scaffolding techniques regarding the improvement of discourse management skills across the two proficiency levels.

\section{The Effect of Cognitive Scaffolding on Interactive Communication}

To address the sixth research question which was pertinent to the impact of cognitive scaffolding on participants' interactive communicative skills and to probe into the possible moderating role of learners' proficiency in mediating the impact of scaffolds on interactional skills, the researcher used a two-way ANCOVA test. Table 8 shows the results of the between-subject effects for the interactive communication component.

Table 8

Two-Way ANCOVA: Tests of Between-Subjects Effects, Interactive Communication Test by Groups* Proficiency

\begin{tabular}{lllllll}
\hline Source & Type III Sum of Squares & Df & Mean Square & F & Sig. & Partial Eta Squared \\
\hline Pretest & 31.23 & 1 & 31.23 & 111.19 & .00 & .49 \\
Groups & 106.12 & 1 & 106.12 & 377.82 & .00 & .76 \\
Proficiency & .20 & 1 & .20 & .74 & .39 & .00 \\
Groups * Proficiency & .32 & 1 & .32 & 1.15 & .28 & .01 \\
\hline Total & 1333.00 & 120 & & & & \\
\hline
\end{tabular}

As Table 8 depicts, in the interaction component, significant differences were detected between the performances of the learners in the scaffolding condition $(M=4.10, S D=$ $.60)$, and the control group $(M=2.15, S D=.65)$, when the pretest scores were taken as the covariate to account for the possible variances prior to the treatment, $F(1,116)=$ $377.82, p<.05 ; \eta 2=.76$. Moreover, as Table 8 displays, the results of the interactive communication two-way ANCOVA test revealed no significant interaction between the groups and proficiency levels, $F(1,116)=1.15, p>.05 ; \eta 2=.01$, revealing no moderating effect for learners' proficiency level.

\section{DISCUSSION}

The present study investigated the role of cognitive scaffolding on speaking skill and its components (grammar, vocabulary, pronunciation, discourse management, interactive communication). In addition, the possible moderating effect of learners' proficiency level on the effect of cognitive scaffolding on the aforementioned dependent variables was examined. The findings of this study provide empirical backing for the effectiveness of scaffolds designed to decrease the cognitive load and to structure learners' cognition. The findings are commensurate with the original theories of scaffolding. According to Bruner (1978), instructional scaffolding that benefits learning entails reduction of "the degrees of freedom in carrying out some task so that the child can concentrate on the difficult skill she is in the process of acquiring" (p. 19). This was achieved through the use of modelling and explanations. Cognitive scaffolding employed in this study intended to structure the task and make it more manageable through instruction and explanations.

Moreover, scaffolds exploited in the study at hand were designed in a way to possess the three features of scaffolds identified by Van de Pol et al. (2010), namely contingency, fading, and transfer of responsibility. To provide contingent support adapted to the 
student's level of learning the teacher should first determine the student's current level of competence via tools such as diagnostic strategies.

In line with previous studies which have regarded online diagnosis (Palincsar \& Brown, 1984), monitoring and checking students' understanding (Garza,2009) as efficient tools for assessing the current level of knowledge, in the present study, questions and one-onone interactions with learners were applied to dynamically assess and determine their competence level and to ensure contingency.

The second shared characteristic of effective scaffolding, fading, was incorporated into the design of scaffolds in the present research as the scaffolds were provided in three phases during which they were gradually removed. Transfer of responsibility, the third feature, was also considered in this study as throughout the aforementioned three stages the learners had to take over more responsibility as they were offered less support.

The results of the present study, hence, endorse the theoretical considerations regarding the effectiveness of contingent scaffolds which are gradually dismantled and make possible the transfer of responsibility in promoting learning. The results, in other words, echo theoretical postulations regarding the effect of contingency and fading of assistance on the acquisition (Van de Pol et al., 2010). Besides, the results corroborate Aljaafreh and Lantolf's (1994) principles dominating the way feedback can be of use to learners. They argued that feedback must be dialogic, graduated, and contingent. The fact that the dialogic contingent, and gradually dismantled scaffolds exploited in this study were found to be effective in promoting speaking skills confirms Aljaafreh and Lantolf's proposal. The dynamic assessment of ZPD and providing contingent feedback in the present study have proved to positively contribute to the quality of learning in this study.

On the whole, the findings of the present study confirm those of previous research reporting that cognitive scaffolding could promote learning. Hence, the findings corroborate the findings of Swanson and Lussier (2001) who reported that cognitive scaffolding via prompting, verbal mediation steps, modeling and feedback for all ages and many different tasks could benefit learning. Cognitive scaffolds assist learners through structuring cognitive activities to decrease the cognitive load and gradually dismantle the assistance, which gives learners the opportunity to little by little experience and be able to handle the intricacy of the task. The findings are also in line with those of Murphy and Messer (2000) who used some scaffolding means such as explanations, instruction, modeling, hints, and questions to study the effects of cognitive scaffolding on the performance of students aged 5 to 7 . The results showed that more children in the scaffolding condition advanced in the level of representation than children working either collaboratively or alone.

Besides, the results corroborate the findings of the previous studies reporting the effectiveness of scaffolds in improving language learning with regard to other skills (e.g. writing skill, Cho \& Schunn, 2007; Veerappan, et al., 2011). The results also add to the existing literature through demonstrating the efficacy of scaffolds in promoting oral skills which was a novel issue. The fact that scaffolding strategies of modeling, instructing, explaining, providing hints, feedback, and questioning could lead to 
improvements in speaking ability reveals the importance of these scaffolding strategies in the context of teaching oral skills.

The findings are in line with the findings of the previous research reporting the positive effects of scaffolding on the speaking skill. The findings echo those achieved by Arfaei Zarandi and Rahbar (2014) who examined the effectiveness of interactive strategies of scaffolding on a cohort of learners' speaking ability. In their study, the experimental group received interactive strategies of scaffolding and the control group experienced routine speaking instruction in ten sessions. The participants were examined in pairs by two examiners, and the results of paired-samples t-test showed that interactive scaffolding strategies were effective in enhancing EFL learners' speaking ability. The results also chime with those of Mulyana (2012) who showed that the exploitation of activities such as working in pairs, gesture, verifying and clarifying students' understanding, motivating, error corrections, modeling, drilling, explaining, and doing elicitation as scaffolding techniques are beneficial in speaking classes.

This study indicated that cognitive scaffolding can advance participants' grammatical knowledge. The findings are in line with studies reporting the usefulness of scaffolds in promoting accuracy. Therefore, the findings of the current study corroborate the findings of a study by Danli (2008) who examined how scaffolding could facilitate the learning of grammatical forms in tertiary Chinese EFL classrooms and reported that scaffolding led to the acquisition of grammatical knowledge. The findings are also commensurate with those of Donato (1994) who reported that receiving scaffolds results in English speakers' gains in learning the French past compound tense of reflective verbs in an oral activity. In line with Donato's (1994) research, in the present study, participants improved with regard to their grammatical knowledge having received scaffolds.

The results also showed that cognitive scaffolding led to improvements in other components of speaking skill such as vocabulary, pronunciation, discourse management and interactive communication. Findings support those of Shoari and Assadi (2015) who reported a positive effect for scaffolding techniques on vocabulary learning. The results also echo those of Mirahmadi and Alavi (2016) who investigated the effect of hard, soft, reciprocal and virtual scaffolding on pronunciation. However, in their study they did not report the incorporation of features specific to scaffolds.

Furthermore, the effect of receiving scaffolds on individuals' ability to speak more coherently, which was addressed in the current study was not previously examined in the literature. Therefore, it is expected that this study motivates researchers to pay due attention to this aspect of oral production while designing and investigating scaffolds.

This study also expanded the previous research through investigation of the role of scaffolding in intrapersonal aspect of speech such as interactive communication. This should stir new line of research looking into the use of scaffolds in interactive processes. Moreover, this study detected no moderating effect for participants' proficiency level, which means that cognitive scaffolds can be adopted at any level to promote learners' oral skills. The results chime with a series of studies carried out by Mortazavi and Jafarigohar $(2016,2017)$ in the context of EFL writing. They reported no moderating 
role for proficiency when scaffolds were applied to assist learners to acquire various aspects of the writing skill. Jafarigohar and Mortazavi (2017) reported that scaffolding could increase both individual and socially-shared metacognition while the learners' proficiency level did not mediate the effect of scaffolds. In another study, Mortazavi, Jafarigohar, and Rouhi (2017) showed that scaffolds could lead to transferability of genre-based knowledge and reported no moderating effect for learners' proficiency level. Mortazavi, Jafarigohar, Rouhi, and Soleimani (2016) also reported no moderating effect for learners' proficiency level when scaffolds were applied to assist acquisition of argumentative writing skills and writing self-regulation.

\section{CONCLUSION}

The findings of this study introduced cognitive scaffolds as effective tools in promoting oral skills. All components of speaking examined in the study were found to be positively affected by cognitive scaffolds designed to lower cognitive burden of the tasks. In other words, learners' knowledge of grammar and vocabulary, pronunciation, discourse, and interactional skills significantly improved as a result of receiving cognitive scaffolds. The results gained in this study are expected to incent EFL instructors to employ scaffolding strategies to improve oral skills. English instructors are encouraged to use various scaffolding means such as prompts, feedback, explanations, and models to help diminish the cognitive burden of the task which would in turn lead to better acquisition of oral skills. The present study illuminates how Van de Pol et al.'s (2010) model can be practically used to provide scaffolding techniques. Given the desired impact of cognitive scaffolds employed in this study on learners' speaking skills, the procedure employed in this study can be copied in similar contexts and introduced in teacher training classes as efficient ways to offer gradually removed scaffolds. The fact that no moderating effect was detected for the proficiency level should motivate practitioners to exploit scaffolding strategies for even low proficient learners and in mixability classes. The present study contributed to the still scarce body of research into the impact of scaffolds on oral skills and is expected to stir a line of research into the ways in which various scaffolding means and intentions can be combined to bring about the optimum results in speaking classes.

\section{REFERENCES}

Abbasian, G. R., Ghahfarokhi, F., \& Ghasemi, M. (2015, May). The effect of off- task scaffolded feedback on young learners' speaking skill. Paper presented at the International Conference on Challenges in ELT \& English Literature (CELT-EL): Facing the Current Issues, Ahar.

Aljaafreh, A., \& Lantolf, J. P. (1994). Negative feedback as regulation and second language learning in the zone of proximal development. The Mdrn Lang. J, 78, 465-483.

Arfaei, Z., \& Rahbar, B. (2014). The impact of interactive scaffolding on Iranian EFL learner`s speaking ability. Int. J. of Lang. Learn. and App. Ling. World, 7(2), 344-353.

Attarzadeh, M. (2011). The effect of scaffolding on reading comprehension of various text modes on Iranian EFL learners with different proficiency levels. Social Sciences and Humanities, 2(4), 1-28. 
Baleghizadeh, S., Timcheh Memar, A., \& Timcheh Memar, H. (2011). A sociocultural perspective on second language acquisition: The effect of high-structured scaffolding versus low-structured scaffolding on the writing ability of EFL learners. Reflections on English Language Teaching, 10(1), 43-54.

Bruner, J. S. (1975). The ontogenesis of speech acts. J. of Child Language, 2, 1-19.

Bruner, J. S. (1978). The role of dialogue in language acquisition. In A. Sinclair, R. J. Jarvelle, \& W. J. M. Levett (Eds.), The child's concept of language (pp. 241-256). New York, NY: Springer Verlag.

Chiu, M. H., Chou, C. C., \& Liu, C. J. (2002). Dynamic processes of conceptual change: Analysis of constructing mental models of chemical equilibrium. Journal of Research in Science Teaching, 39, 688-712.

Cho, K. \& Schunn, C. (2007). Scaffolded writing and rewriting in the discipline: A web based reciprocal peer review system. Computers and Education, 48(3), 409-426.

Danli, L. (2008). Scaffolding and its impact on learning grammatical forms in tertiary Chinese EFL classrooms (Unpublished doctoral dissertation). Hong Kong Baptist University, Hong Kong.

De Guerrero, M. C. M., \& Villamil, S. O. (2000). Activating the ZPD: Mutual scaffolding in L2 peer revision. Modern Language Journal, 84(1), 51-68.

Donato, R. (1994). Collective scaffolding in second language learning. In J. P. Lantolf, \& G. Appel (Eds.), Vygotskian approaches to second language research (pp. 33-56). Ablex, Norwood: NJ.

Garza, R. (2009). Latino and white high school students' perceptions of caring behaviors: Are we culturally responsive to our students? Urban Education, 44, 297-321.

Ghafar Samar, R., \& Dehqan, M. (2013). Sociocultural theory and reading comprehension: The scaffolding of readers in an EFL context. International Journal of Research Studies in Language Learning, 2(3), 67-80.

Helmer-Salasoo, E. (2001). Social context and instructional scaffolding in a literaturebased high school classroom of English Language learners (Unpublished doctoral dissertation). State University of New York, Albany.

Hemmati, F., \& Mortazavi, M. (2017). The effect of different types of written scaffolds on EFL learners' perception of writing self-regulatory skills. Reading \& Writing Quarterly, 33(1), 71-81.

Huggins, G. E., \& Edwards, R. (2011). Scaffolding to improve reading comprehension and to write a scholarly research paper. Int. J. of Human. and Soc. Sci., 1(16), 30-36.

Hughes, R. (2002). Teaching and researching speaking. Harlow: Pearson Education.

Jacobs, G. (2001). Providing the scaffold: A model for early childhood/primary teacher preparation. Early Childhood Education Journal, 29, 125-130.

Jafarigohar, M., \& Mortazavi, M. (2016). Promoting metacognition in EFL classrooms through scaffolding motivation. Iranian J. of Applied Linguistics (IJAL), 19(1), 73-98. 
Khaliliaqdam, S. (2014). ZPD, scaffolding and basic speech development in EFL context. Procedia-Social and Behavioral Sciences, 98, 891 - 897.

Magno, C. (2010). The effect of scaffolding on children is reading speed, reading anxiety, and reading proficiency. TESOL Journal, 3, 92-98.

Maybin, J., Mercer, N., \& Stierer, B. (1992). Scaffolding: Learning in the classroom. In: K. Norman (Eds.), Thinking voices: The work of the national oracy project (pp. 186195). London: Hodder \& Stoughton.

McCarthy, M. \& O'Keeffe, A. (2006). Speaking in a second language. In M. Berns (Eds.), Concise encyclopedia of applied linguistics (pp. 212-218). Oxford: Elsevier.

Mattanah, J. F., Pratt, M. W., Cowan, P. A., \& Cowan, C. P. (2005). Authoritative parenting, parental scaffolding of long-division mathematics, and children's academic competence in fourth grade. Journal of Applied Developmental Psychology, 26, 85-106.

Mertzman, T. (2008). Individualizing scaffolding: Teachers' literacy interruptions of ethnic minority students and students from low socioeconomic backgrounds. Journal of Research in Reading, 31, 183-202.

Mortazavi, M., Jafarigohar, M., Rouhi, A., \& Soleimani, H. (2016). The effect of scaffolding through structuring and problematizing on EFL learners' writing selfregulatory skills, essay writing skill and global planning time, Quarterly Journal of Research in School and Virtual Learning, 4(3), 15-26.

Mortazavi, M., Rouhi, A., \& Jafarigohar, M. (2017). Can scaffolding mechanisms of structuring and problematizing facilitate the transfer of genre-based knowledge to another discourse mode? Journal of Teaching Language Skills (JTLS) 35(4), 133-156.

Murphy, N., \& Messer, D. (2000). Differential benefits from scaffolding and children working alone. Educational Psychology, 20, 17-31.

Mulyana, A. (2012). The use of scaffolding in teaching speaking (Unpublished master thesis). University of Pendidikan, Indonesia.

Newman, F., \& Holzman, L. (1993). Lev Vygotsky: Revolutionary scientist. New York, NY: Routledge.

Palincsar, A., \& Brown, A. (1984). Reciprocal teaching of comprehension-fostering and comprehension-monitoring activities. Cognition and Instruction, 1, 117-175.

Pino-Pasternak, D., Whitebread, D., \& Tolmie, A. (2010). A multidimensional analysis of parent-child interactions during academic tasks and their relationships with children's self-regulated learning. Cognition and Instruction, 28, 219-272.

Poorahmadi, M. (2009). The effect of employing scaffolding strategies and classroom tasks in teaching reading comprehension. Journal of Teaching English as a Foreign Language and Literature, 1(3), 87-106.

Pratt, M. W., \& Savoy-Levine, K. M. (1998). Contingent tutoring of long-division skills in fourth and fifth graders: Experimental tests of some hypotheses about scaffolding. Journal of Applied Developmental Psychology, 19, 287-304. 
Rahimi, A., \& Ghanbari, N. (2011). The impact of teachers' scaffolding on Iranian high school students' reading comprehension. Procedia -Soc. and Beh. Sci., 28, 1072 - 1075.

Rahimi, A., \& Tahmasebi, S. (2010). Mediating Iranian EFL learners: private speech and Scaffolding in reading comprehension. Linguistic and Literary Broad Research and Innovation, 1(2), 56-71.

Riazi, M. \& Rezaii, M. (2011). Teacher- and peer-scaffolding behaviors: Effects on EFL students' writing improvement. In A. Feryok (Eds.), CLESOL 2010: Proceedings of the 12-national conference for community languages and ESOL (pp. 55-63). Wellington: TESOLANZ.

Rueda, R., Monzo, L. D., \& Higareda, I. (2004). Appropriating the sociocultural resources of Latino paraeducatfor effective instruction with Latino students-Promise and problems. Urban Education, 39, 52-90.

Shoari, E., Assadi Aidinlou, N. (2015). Zone of proximal development: The effect of verbal scaffolding on improving Iranian young EFL learners' vocabulary learning. Journal of Applied Linguistics and Language Research, 8(2), 208-217.

Stright, A. D., Neitzel, C., Sears, K. G., \& Hoke-Sinex, L. (2001). Instruction begins in the home: Relations between parental instruction and children's self-regulation in the classroom. Journal of Educational Psychology, 93, 456-466.

Swanson, H. L., \& Lussier, C. M. (2001). A selective synthesis of the experimental literature on dynamic assessment. Review of Educational Research, 71, 321-363.

Tyas, D. A. P. (2009). Teachers' scaffolding talks in teaching speaking (Unpublished master thesis). Semarang State University, Indonesia.

Van de Pol, J., Volman, M., \& Beishuizen, J. (2010). Scaffolding in teacher-student interaction: A decade of research. Educational Psychology Review, 22, 271-297.

Veerappan, V.A.L., Suan, W.H., \& Sulaiman, T. (2011). The Effect of scaffolding technique in journal writing among the second language learners. Journal of Language Teaching and Research, 2(4), 934-940.

Vyotsky, L. (1978). Mind in society: The development of higher psychological processes. Cambridge: Harvard University Press.

Waniek-Klimczak, E., \& Pawlak, M. (Eda.). (2015). Teaching and researching the pronunciation of English. New York, NY: Springer.

Wittwer, J., \& Renkl, A. (2008). Why instructional explanations often do not work: A framework for understanding the effectiveness of instruction explanations. Educational Psychologist, 43, 49-64.

Wood, D., \& Middleton, D. (1975). A study of assisted problem solving. British Journal of Psychology, 66, 181-191.

Wood, D., Wood, H., \& Middleton, D. (1978). An experimental evaluation of four faceto-face teaching strategies. Int. Journal of Behavioral Development, 1, 131-147. 